\title{
DO NOT BE AFRAID OF SMALL HIGH-SPEED FRANCIS TURBINES
}

\author{
KOUDELKA Libor ${ }^{1}$ \\ ${ }^{I}$ Development of Water Turbines, Strojírny Brno, ,Blanenská 55, 66434 Kuřim, Czech Republic, \\ e-mail: l.koudelka@strojirnybrno.cz.
}

\begin{abstract}
In the first quarter of the last century hydraulic power plants were equipped with high-speed Francis turbines even in the situation when a contemporary project manager would suggest Kaplan turbine. The reason is simple. Mr. Kaplan patented his turbine only in 1912 [1], https://en.wikipedia.org/wiki/Viktor_Kaplan . Those high-speed Francis turbines have just reached their lifetime. Mainly runners need repair. Our customers' respond is that even renowned firms refuse to deliver runners with better parameters. Offer is to replace whole turbine with Kaplan or to make a copy of the existing runner. This paper presents experience and results of such a highspeed runner design. The runner substituted the one of Prokopa \& sons from 1939 in powerhouse and mill at Křemže stream. Virtual prototyping technique has been used.
\end{abstract}

KEYWORDS: Francis turbine, runner, refurbishment, CFD, virtual prototype.

\section{Introduction}

This article deals with concrete design of a Francis runner as a replacement of an old one installed already in 1939 in powerhouse and mill at Křemže stream. Since the small power plant is not a national heritage the owner could start the refurbishment. This consisted of new generator, new guide vanes but as a copy of the old ones, repair or manufacture of some parts and fitting the turbine up with a new runner. The runner is just the subject of the paper. The event had a personal meaning for the owner since the mill has been a family private property for a long time. That is why I provide the article with some story.

The owner expected to get a runner with higher efficiency and made from stainless steel. It is easy to meet the second condition. First one was a problem. He turned to a respected Czech turbine producer and got rather surprising answer. There does not exist a better runner than he has. He was offered with an exchange for a Kaplan bulb turbine. Such an investment seemed to be too expensive. Being aware of modern CFD methods he refused to accept the verdict that there is no chance to get better design than that from 1939. He contacted Strojírny Brno and we accepted the challenge. The goal was to get maximum electric output of $13 \mathrm{~kW}$. This means increase in power and efficiency by $13 \%$. The paper is not aimed at complete methodology of Francis runner design. Nevertheless it shows main directions where to go when somebody meets the problem of refurbishment of a small high-speed Francis turbine. Also a method to estimate computational error of total power output from such limited data sources is presented. 


\section{Nomenclature}

Table 1

\begin{tabular}{|c|c|c|c|c|}
\hline $\begin{array}{c}\text { Constant } \\
\text { or } \\
\text { variable } \\
\end{array}$ & Definition & Unit & Value & Description \\
\hline $\mathrm{D}$ & & $\mathrm{m}$ & 0.35 & Runner diameter. \\
\hline $\mathrm{n}$ & & $/ \mathrm{min}$ & 470 & Runner speed. \\
\hline$\rho$ & & $\mathrm{kg} / \mathrm{m}^{3}$ & 999 & Water specific weight at $20^{\circ} \mathrm{C}$. \\
\hline $\mathrm{g}$ & & $\mathrm{m} / \mathrm{s}^{2}$ & 9.81 & Gravitational acceleration. \\
\hline $\mathrm{T}$ & & $\mathrm{Nm}$ & & Torque at turbine shaft axis. \\
\hline $\mathrm{p}_{\mathrm{a}}$ & & $\mathrm{Pa}$ & 101000 & Atmospheric pressure. \\
\hline $\mathrm{p}_{1}$ & $\mathrm{p}_{2}+\rho \mathrm{g} \mathrm{H}_{\mathrm{G}}$ & $\mathrm{Pa}$ & 25455 & $\begin{array}{l}\text { Inlet total pressure specifying } \\
\text { gross head. See fig. } 7 \text {. }\end{array}$ \\
\hline $\mathrm{p}_{2}$ & $-\rho g \mathrm{H}_{\mathrm{s}}$ & $\mathrm{Pa}$ & -21539 & $\begin{array}{l}\text { Outlet total pressure specifying } \\
\text { gross head. See fig. } 7 \text {. }\end{array}$ \\
\hline $\mathrm{H}_{\mathrm{G}}$ & $\frac{p_{1}-p_{2}}{g H}$ & $\mathrm{~m}$ & 4.6 & Gross head. \\
\hline $\mathrm{p}_{\text {in }}$ & & $\mathrm{Pa}$ & Computed. & $\begin{array}{l}\text { Total pressure at the control } \\
\text { volume inlet. See fig. } 7 .\end{array}$ \\
\hline $\mathrm{p}_{\text {out }}$ & & $\mathrm{Pa}$ & Computed. & $\begin{array}{l}\text { Total pressure at the control } \\
\text { volume outlet. See fig. } 7 .\end{array}$ \\
\hline $\mathrm{H}$ & $\frac{p_{\text {in }}-p_{\text {out }}}{\rho g}$ & $\mathrm{~m}$ & & Net head. \\
\hline $\mathrm{H}_{\mathrm{s}}$ & & $\mathrm{m}$ & 2.2 & Suction head. \\
\hline $\mathrm{n}_{11}$ & $\frac{\mathrm{n} \cdot \mathrm{D}}{\sqrt{\mathrm{H}}}$ & $/ \mathrm{min}$ & 75.1 & Unit runner speed [3]. \\
\hline $\mathrm{n}_{\mathrm{ED}}$ & $\frac{\mathrm{n} \mathrm{D}}{60 \sqrt{\mathrm{gH}}}$ & & 0.4 & Speed factor $[5]$. \\
\hline$\omega$ & $\frac{2 \pi n}{60}$ & $\mathrm{rad} / \mathrm{s}$ & 49.22 & Angular velocity of the runner. \\
\hline $\mathrm{Q}$ & & $\mathrm{m}^{3} / \mathrm{s}$ & & Flow rate. \\
\hline $\mathrm{Q}_{11}$ & $\frac{Q}{\mathrm{D}^{2} \sqrt{\mathrm{H}}}$ & $\mathrm{m}^{3} / \mathrm{s}$ & & Unit flow rate [3]. \\
\hline QED & $\frac{\mathrm{Q}}{\mathrm{D}^{2} \sqrt{\mathrm{gH}}}$ & & & Discharge factor [5]. \\
\hline$\eta_{\mathrm{H}}$ & $\frac{\mathrm{T} \omega}{\rho g H Q}$ & & & Hydraulic (turbine) efficiency. \\
\hline$\eta_{\mathrm{G}}$ & & & & Generator efficiency. \\
\hline$\eta_{\text {в }}$ & & & 0.91 & $\begin{array}{l}\text { Efficiency of belt transmission } \\
\text { [4]. }\end{array}$ \\
\hline$\eta$ & $\eta_{\mathrm{H}} \eta_{\mathrm{G}} \eta_{\mathrm{B}}$ & & & Turbogenerator efficiency. \\
\hline $\mathrm{P}$ & $\rho \mathrm{g} \mathrm{H} Q \eta_{\mathrm{H}} \eta_{\mathrm{G}} \eta_{\mathrm{B}}$ & & & $\begin{array}{l}\text { Total power output of } \\
\text { turbogenerator. }\end{array}$ \\
\hline
\end{tabular}




\section{State before reconstruction}

Parameters of the turbine in powerhouse and mill at Křemže stream. Fig. 1 gives the evidence of data.

Table 2

\begin{tabular}{|l|c|}
\hline Runner diameter. & $0.35 \mathrm{~m}$ \\
\hline Number of runner blades. & 10 \\
\hline Number of guide vanes. & 10 \\
\hline Gross head. Now by $0.2 \mathrm{~m}$ lower then projected. & $4.6 \mathrm{~m}$ \\
\hline Suction head & $2.2 \mathrm{~m}$ \\
\hline Maximum discharge. & $0.37 \mathrm{~m}^{3} / \mathrm{s}$ \\
\hline Maximum hydraulic power. & $11.5 \mathrm{~kW}$ \\
\hline Maximum electric power. & $1.38 \mathrm{~m}^{3} / \mathrm{s}$ \\
\hline Q11 $_{11}$ at maximum discharge. & 0.44 \\
\hline QED at maximum discharge. & $\mathrm{HP}=13.72 \mathrm{~kW}$ \\
\hline
\end{tabular}

The turbine was designed at operation point $\mathrm{n}_{\mathrm{ED}}=0.4\left(\mathrm{n}_{11}=75.1\right)$ and $\mathrm{Q}_{\mathrm{ED}}=0.44\left(\mathrm{Q}_{11}=\right.$ 1.38 ). Since the designer had to use Francis turbine he chose the speed of $570 / \mathrm{min}$ to get suitable value of $\mathrm{n}_{\mathrm{ED}}$. If we take into consideration the small gross head it is quite clear that Kaplan bulb turbine with runner speed about $800 / \mathrm{min}$ is the best solution.

It is necessary to give translation to English of some nomenclature used in Fig. 1.

Table 3

\begin{tabular}{|l|l|}
\hline Expression & English meaning \\
\hline Hydrotechnický výpočet. & Calculation of hydraulic design. \\
\hline D & Runner diameter. \\
\hline i & Number of guide vanes. \\
\hline a & Maximum opening of guide vanes. Known as maximum $\mathrm{a}_{0}$. \\
\hline b & Height of guide vane. \\
\hline Q & Maximum discharge in litres. \\
\hline N & Maximum hydraulic power in HP. \\
\hline
\end{tabular}

\section{$4 \quad$ Reverse engineering}

To be able to do an analysis of a difference between the turbine with old and new runner it was of great importance to get 3D model of the existing runner. Other reason was to get fitting dimensions for the new one. Inlet height and diameters, overall height and outlet diameter. Old runner was scanned and 3D model was prepared. 


\title{
Hydrotechnický výpočet
}

\author{
pro pana Bedrúicha $C i$ ž $\mathrm{k}$ a , mlýn a elektrárna \\ $v$ Kremzii, lide na místo spirciní Francisovy turbiny \\ mé se postavit horizontálnf Francisova turbina kole- \\ nová, konstruovaná pro spéd $4.8 \mathrm{~m}$ a má ty to rozwẻry:
}

Prủmèr obèžného kola . . . . . . . . . . . . D = $350 \mathrm{~mm}$

Počet rozváděcích lopatek . . . . . . . . . $i=10$

Největši otevření rozvádĕcích lopatek . . . . . . . a $=80 \mathrm{~mm}$

Výska rozváděcích lopatek ................. Největš́ ú úhel posled. elementu lopatky kola rozváděciho s tangentou $\alpha=40^{\circ}$

Úhel posledního elementu lopatky kola oběžného s tangentou $. \beta=165^{\circ}$

Největši prútokový prúřez ve výstupu vody z rozváděcího kola jest : $F=i \times a \times b=10 \times 0.080 \times 0.13=0.104 \mathrm{~m}^{2}$

Rychlost vody $\mathrm{v}$ tomto prúřezu jest :

$$
C=\sqrt{\operatorname{ggH} \sqrt{\frac{\sin \beta}{\sin (\beta-z) \times \cos z}}}
$$

kde $\varepsilon=0.8$ a značí hydraulický stupeň účinnosti turbiny, $g=9.81 \mathrm{~m} / \mathrm{sek}^{2}$ a znači přirychlení zemské tíze.

Jest tedy $\quad C=\sqrt{0.8 \times 9.81 \times 4.8} \sqrt{0.403}=3.9 \quad m$ za vteřinu.

Největší množství vody, které mưže turbinou protéci, jest:

$$
Q=\vdots \times F \times C \text {, }
$$

$k$ de $\varsigma=0.91$ a znači koeficient skutečného prôtoku po odečtení ztrát př̀i přechodu vody z kola rozváděcího do obèžného. - Jest tedy

$Q=0.51 \times 0.104 \times 3.9=0.370 \mathrm{~m}^{3} / \mathrm{sec}=370 \quad$ litrú za vteřinu.

Největı̌́ výkon turbiny jest:

$$
N=\frac{1000 \times Q \times H \times t_{i}}{75}
$$

kde $r_{1}=0.78$ a značí účinnost vodni turbiny.

Jest tedy

$$
N=-1000 \times 0.37 \times 75
$$

4.8

$\times 0.78=18.4$ koňských sil.

V PARDUBICfCH dne 3. ̌ervna 1939.

Jos. Prokopa synovê.

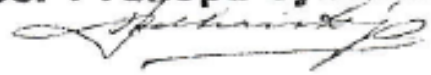

Fig. 1 Original document with hydraulic calculation [2]. 


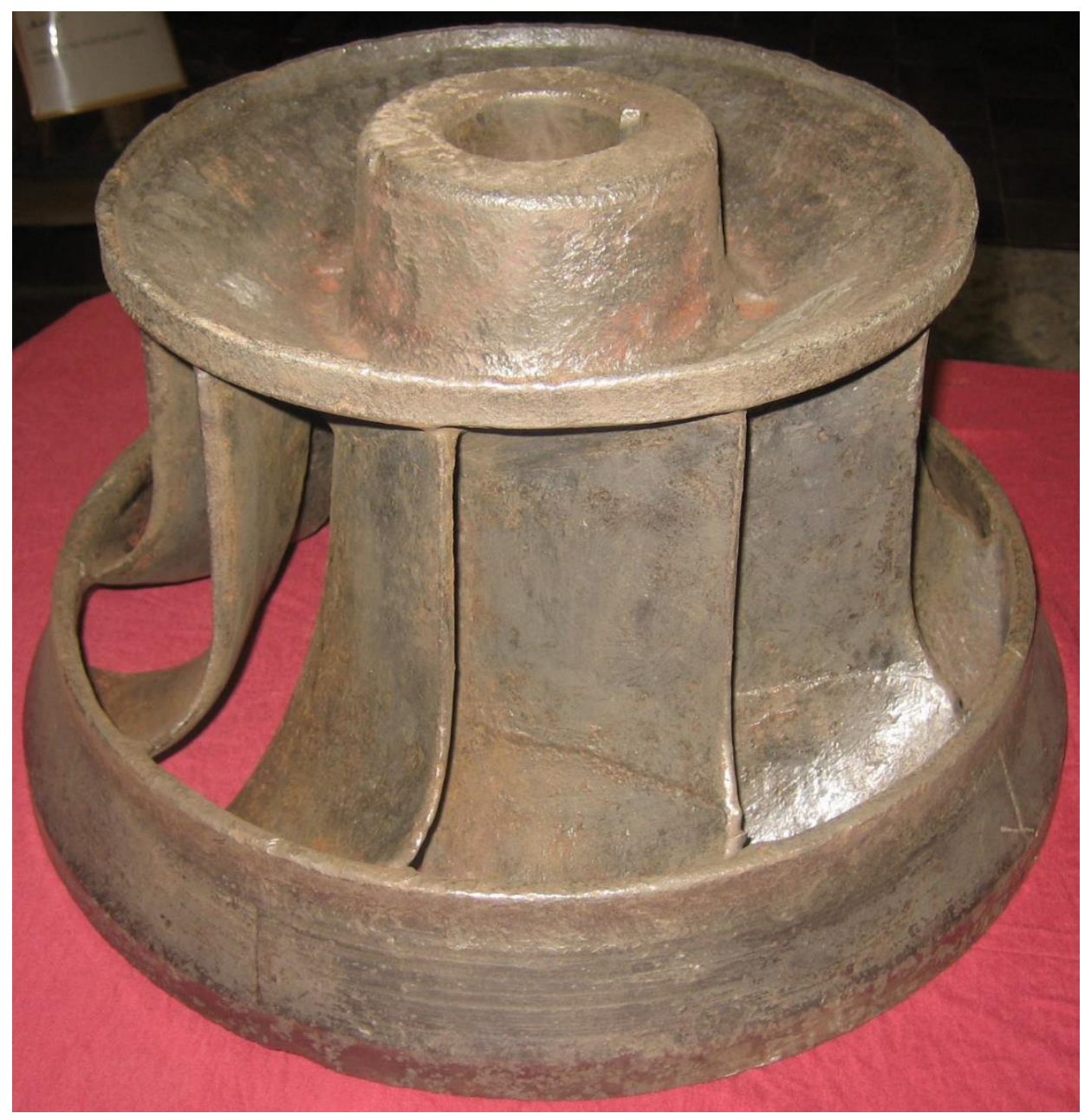

Fig. 2 Original runner.

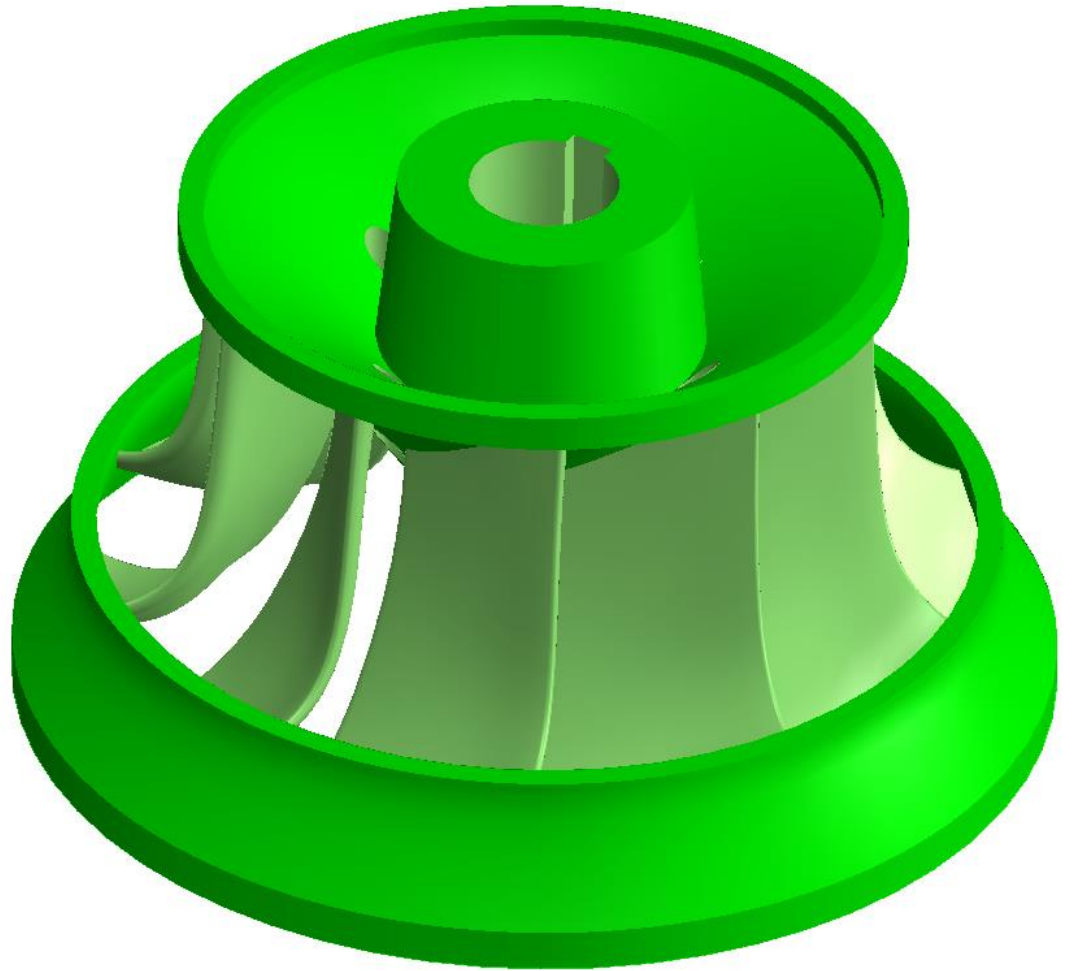

Fig. 3 Scan of the original runner. 
Designer equipped with runner model can easily cut out meridian curve and one blade. These serve as input to Numeca Autogrid. See fig. 4.

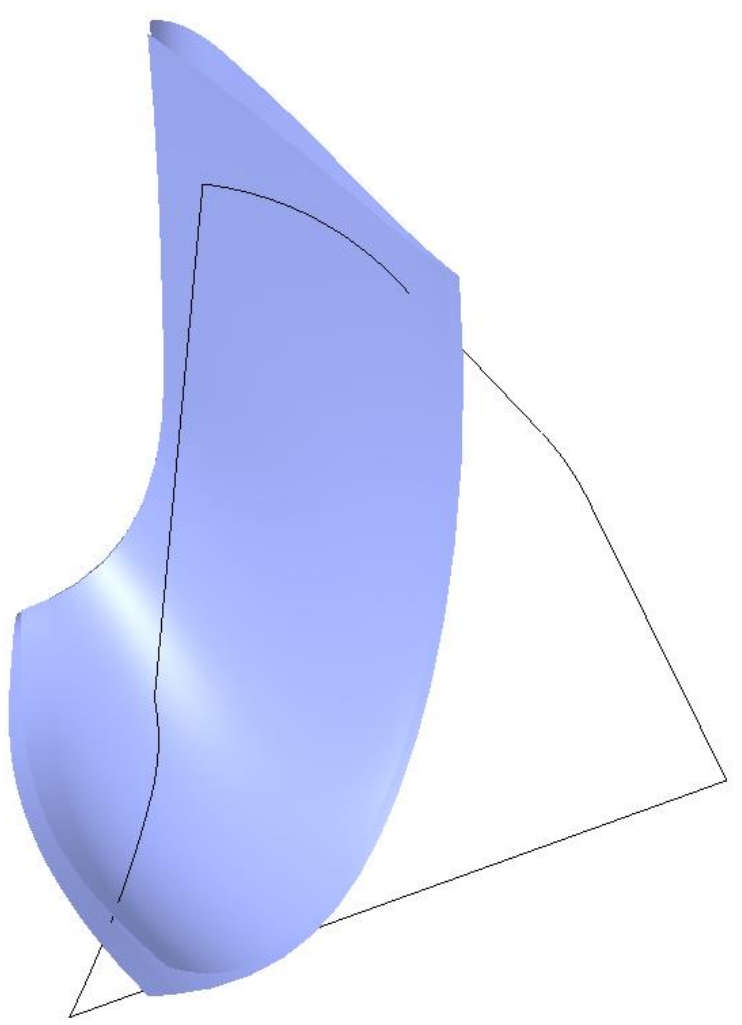

Fig. 4 Meridian section curve and blade surface.

Resulting cyclical symmetric section of the runner can be seen in fig. 5 . There one periodic and runner inlet surfaces are removed. 


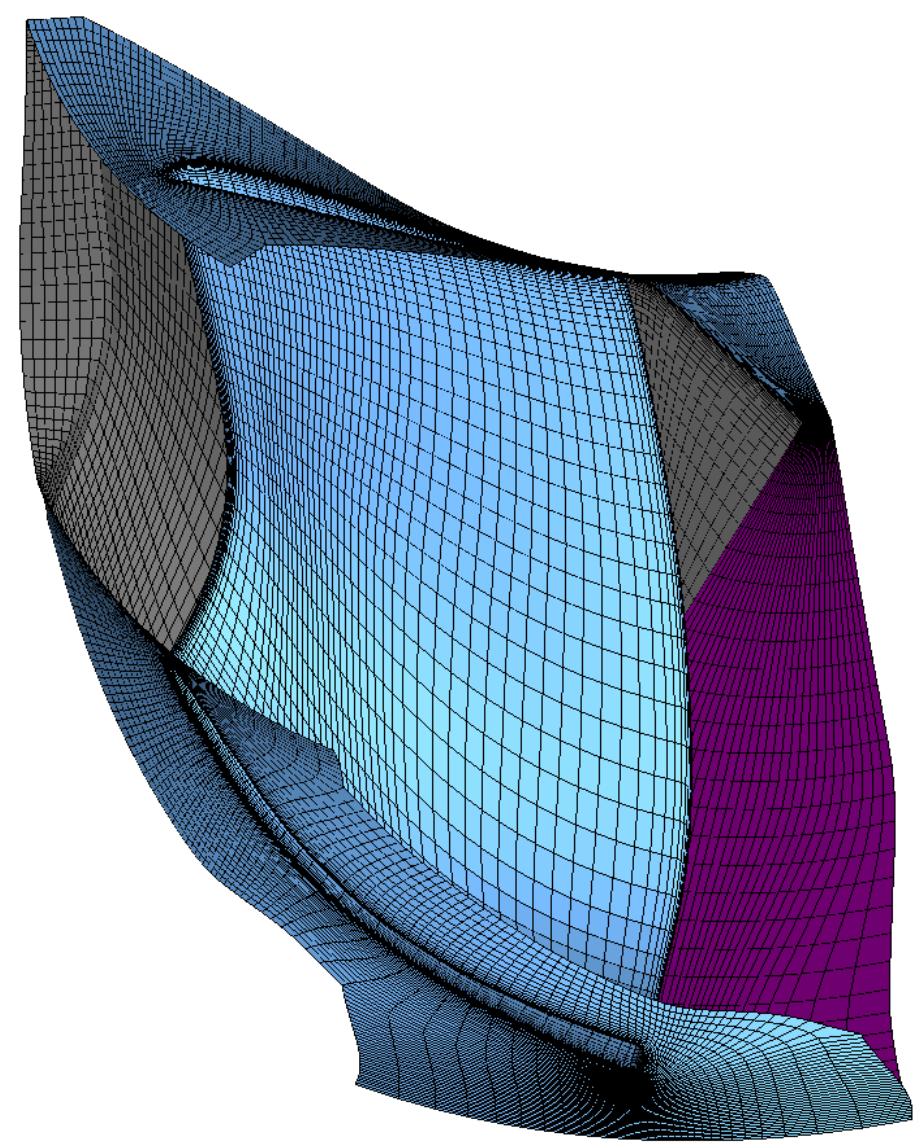

Fig. 5

\section{$5 \quad$ Runner design}

During hydraulic design following software has been used.

Table 4

\begin{tabular}{|l|l|l|}
\hline \multicolumn{1}{|c|}{ Software } & \multicolumn{1}{c|}{ Producer } & \multicolumn{1}{c|}{ Purpose } \\
\hline Ansys CFD & Ansys & CFD computation, pre and post processing. \\
\hline Autogrid & Numeca & Blade meshing. \\
\hline Solid Works & Dassault Systems & 3D modeling. \\
\hline Creo & PTC & 3D modeling. \\
\hline Runner blade & In-house & Runner blade shape computation. \\
\hline
\end{tabular}

\subsection{Virtual prototype}

Virtual prototyping is so strong tool that small water turbines do not undergo any experimental verification. Anyway it is necessary to have drawings to be able to prepare the prototype. It was a piece of luck that there was enough documentation to enable to get $3 \mathrm{D}$ model. Part of it can be seen in following figure [2].

Virtual prototype parameters correspond with real site conditions. See also table 1. 


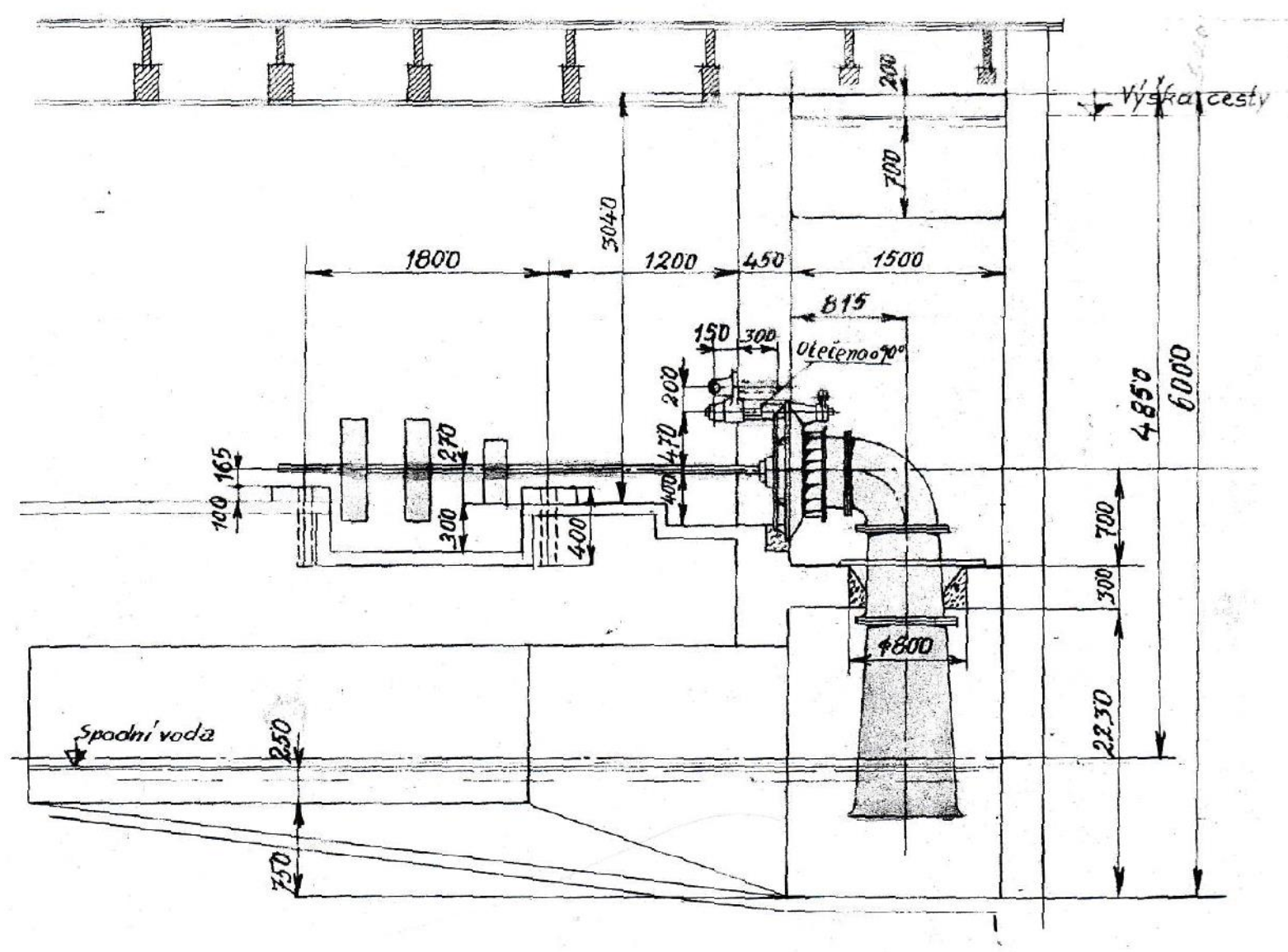

Fig. 6 Original drawing cut-out [2].

Table 5. Virtual prototype parameters.

\begin{tabular}{|l|c|}
\hline Runner diameter. & $350 \mathrm{~mm}$ \\
\hline Number of runner blades old runner / new runner. & $10 / 11$ \\
\hline Number of guide vanes. & 10 \\
\hline Maximum opening of guide vanes. & $\mathrm{a}_{0}=82 \mathrm{~mm}$ \\
\hline Guide vane opening range. & $\mathrm{a}_{0}=29-77$ \\
\hline Gross head. & $4.8 \mathrm{~m}$ \\
\hline Net head. & $\sim 4.6 \mathrm{~m}$ \\
\hline Suction head . & $2.2 \mathrm{~m}$ \\
\hline Runner speed. Old / new runner & $400 / 470 \quad / \mathrm{min}$. \\
\hline Flow range. & $0.1-0.38 \mathrm{~m}^{3} / \mathrm{s}$ \\
\hline
\end{tabular}




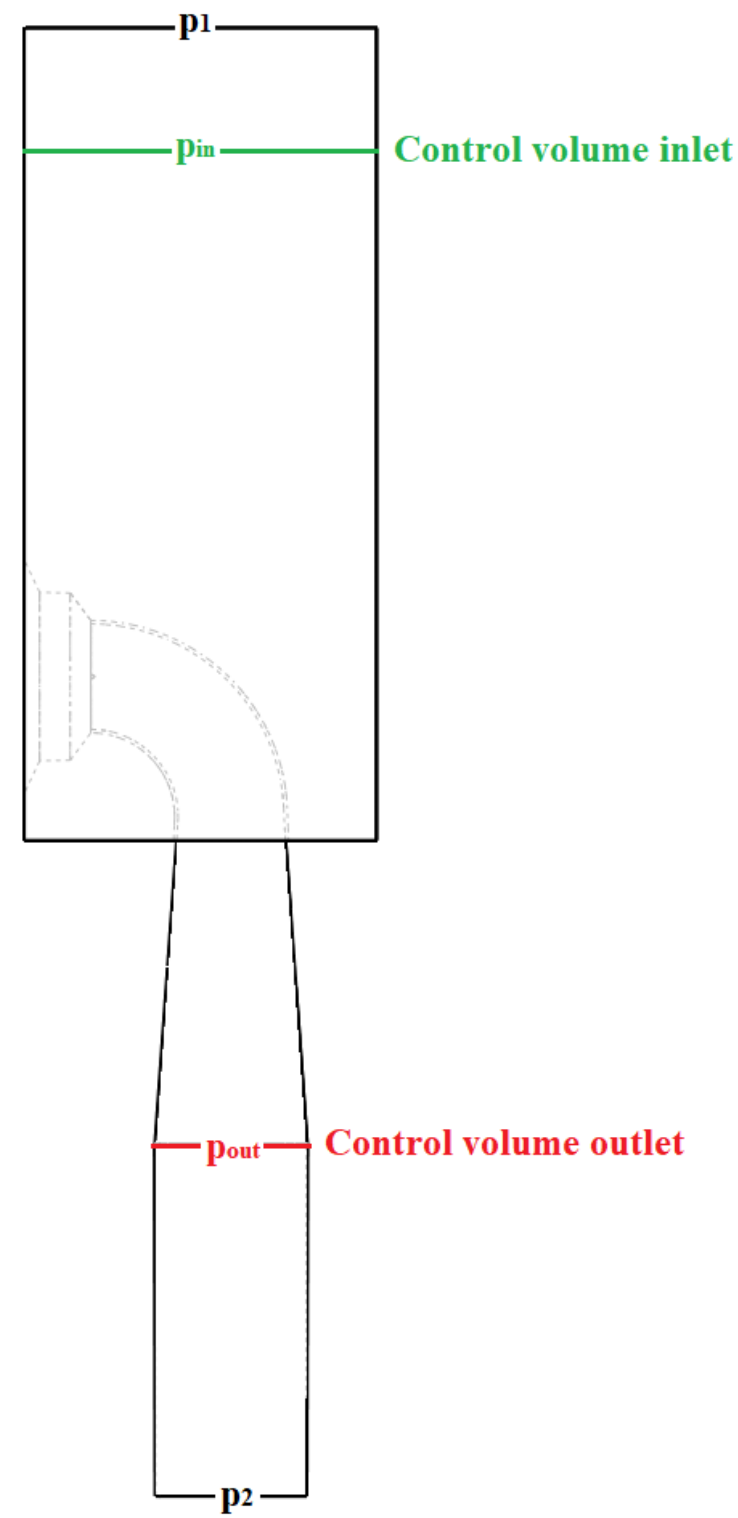

Fig. 7. Scheme of the virtual prototype with boundary conditions.

Well known technique of cyclic symmetry has been used to model guide vanes and runner. Here Autogrid by Numeca proved to be powerful. It is enough to have blade surface and meridian curves to get quality cyclically symmetric sector. See also fig. 4 . 


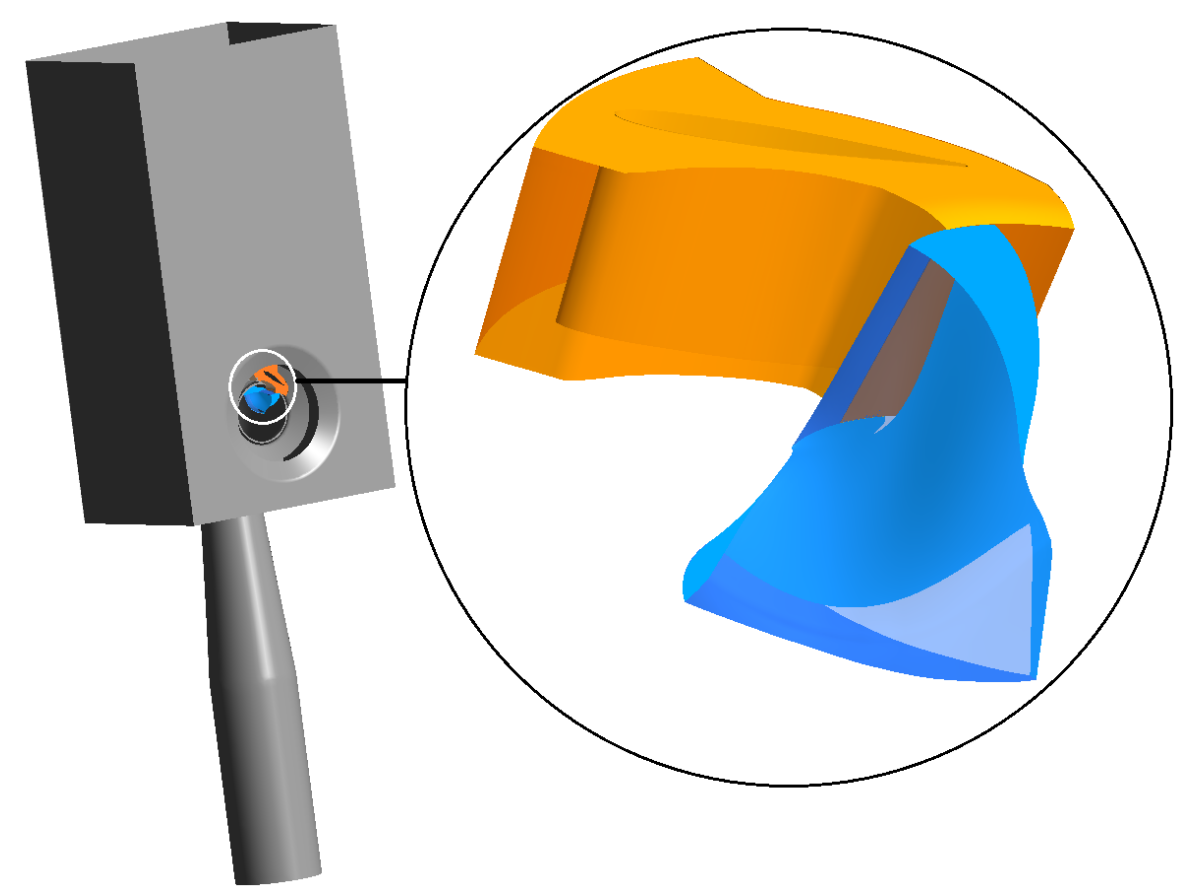

Fig. 8 Virtual prototype with detail of cyclic symmetry for guide vane and runner.

\subsection{Method}

To get better result it is quite clear at first sight that more sophisticated wing shape can be used for runner blades. Following figures compare shapes of the old and new runner blade respectively. New blade is also thinner and has bigger surface area. Pressure side surface area of the old blade is $2.1 \mathrm{dm}^{2}$ and $2.5 \mathrm{dm}^{2}$ of the new one. There is even one more blade in new runner corresponding hub and shroud meridian. In this way it is possible to get higher torque at runner shaft axis with same hydraulic conditions which means higher efficiency and power output. Shape of the blade must be incorporated into the virtual prototype and verified by CFD. Then sequential iterations give desired result.

Table 6. Blade shapes with plane sections.

\begin{tabular}{|l|l|}
\hline Old blade. & New blade. \\
\hline
\end{tabular}




\section{Results and discussion}

It has been mentioned that the goal of the refurbishment was to get generator power output of $13 \mathrm{~kW}$. The generator is Siemens with maximum output of $15 \mathrm{~kW}$. Efficiency dependence on load given by Siemens is according to following graph.

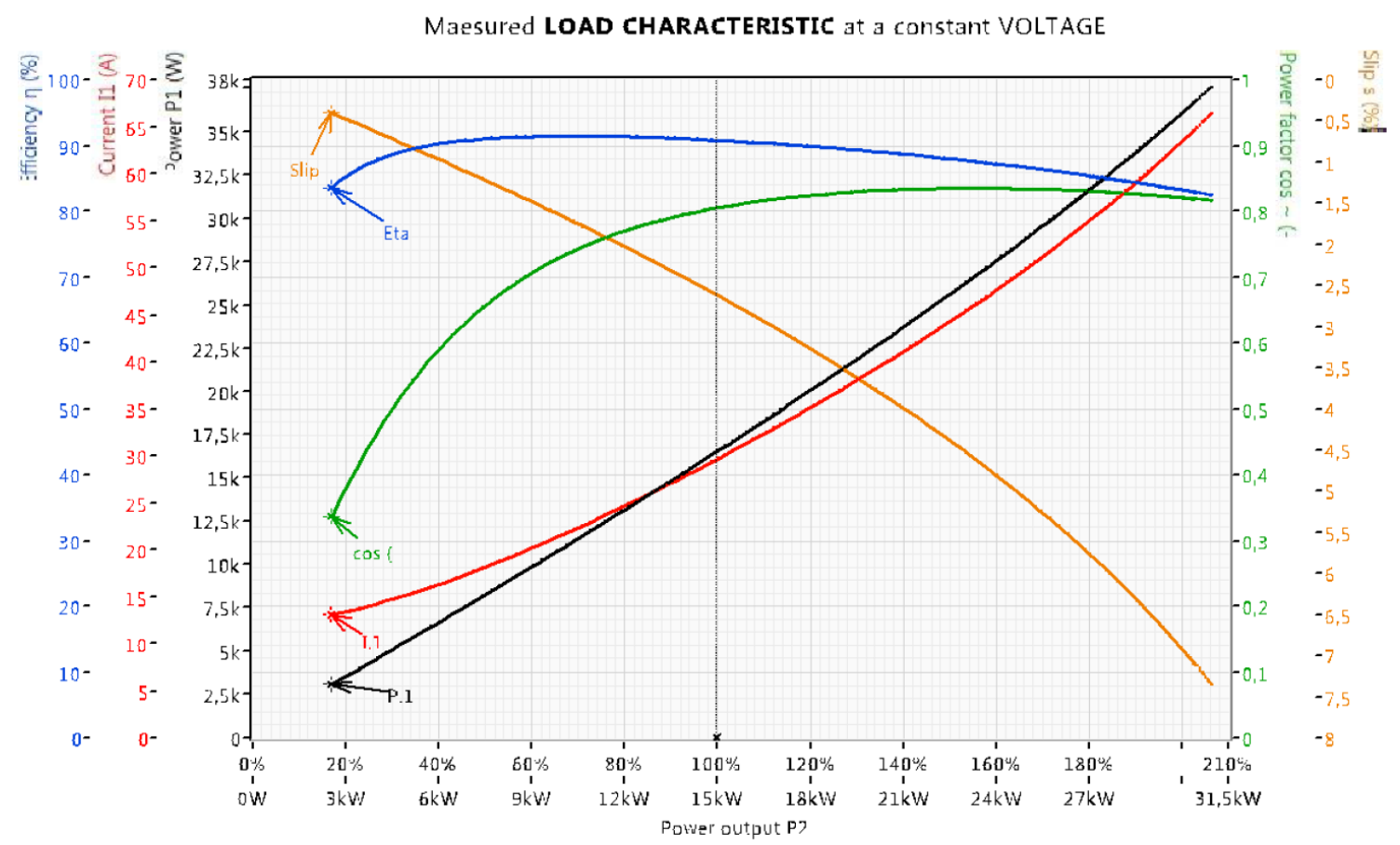

Graph 1 Blue curve is of the interest.

Generator is driven by a belt transmission with efficiency of $91 \%$ [4] .

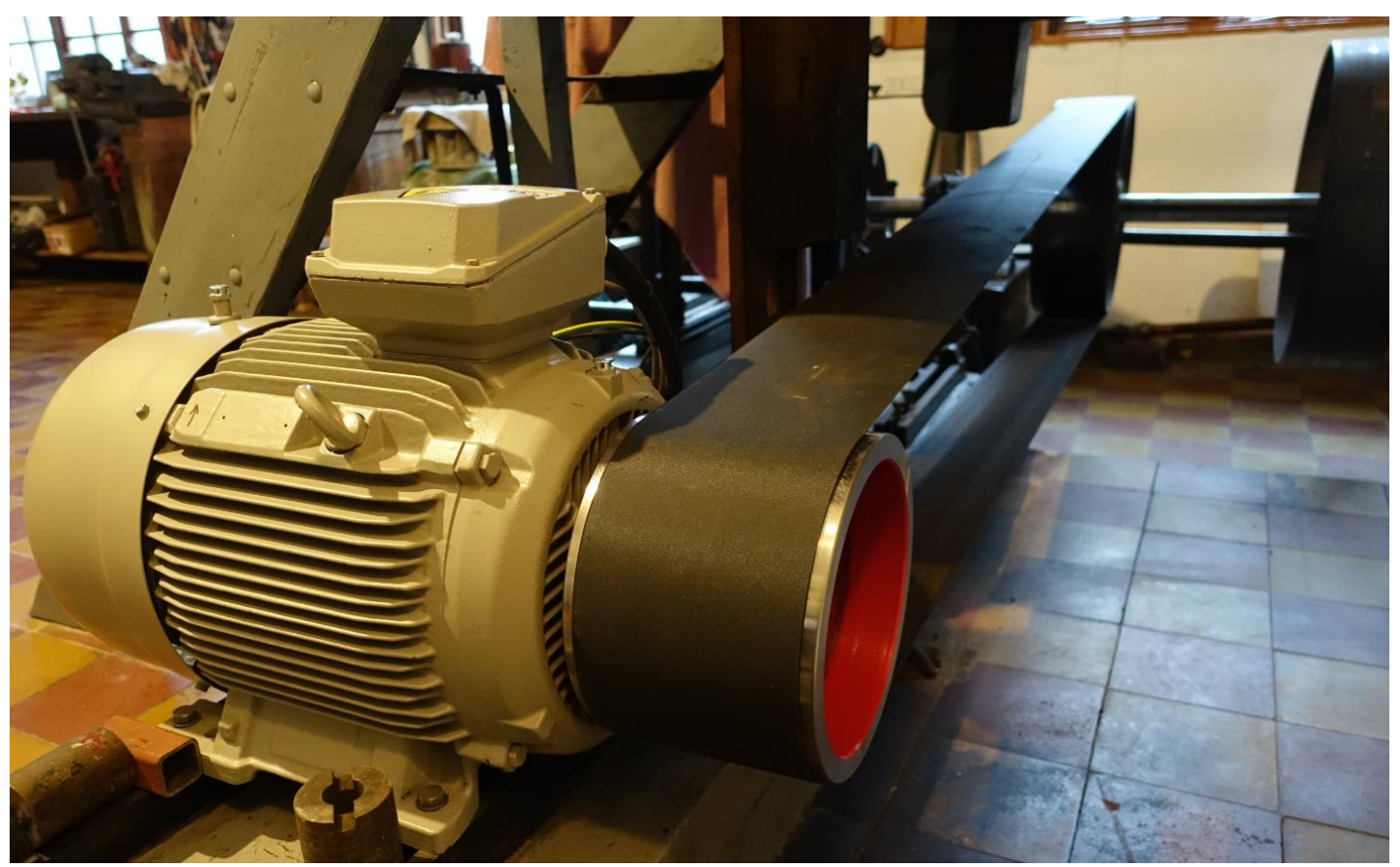

Fig. 9 Belt transmission from turbine to generator shaft. 
Table 7. Computed data of original turbo generator.

\begin{tabular}{|c|c|c|c|c|c|c|}
\hline $\begin{array}{c}\mathbf{Q} \\
{\left[\mathbf{m}^{\mathbf{3} / \mathbf{s}}\right]}\end{array}$ & $\begin{array}{c}\mathbf{a 0} \\
{[\mathbf{m m}]}\end{array}$ & $\begin{array}{c}\text { Guide vane } \\
\text { opening } \\
{[\%]}\end{array}$ & $\begin{array}{c}\boldsymbol{\eta}_{\mathbf{H}} \\
{[\mathbf{\%}]}\end{array}$ & $\begin{array}{c}\mathbf{\eta}_{\mathbf{G}} \\
{[\mathbf{\%}]}\end{array}$ & $\begin{array}{c}\mathbf{\eta} \\
{[\mathbf{\%}]}\end{array}$ & $\begin{array}{c}\mathbf{P} \\
{[\mathbf{k W}]}\end{array}$ \\
\hline 0.141 & 29 & 35 & 74.9 & 87.0 & 59.3 & 3,8 \\
\hline 0.191 & 38 & 46 & 81.3 & 90.0 & 66.6 & 5,7 \\
\hline 0.250 & 48 & 59 & 86.4 & 91.0 & 71.5 & 8,1 \\
\hline 0.283 & 53 & 65 & 88.1 & 92.0 & 73.8 & 9,4 \\
\hline 0.330 & 62 & 76 & 86.3 & 92.0 & 72.3 & 10,7 \\
\hline 0.388 & 75 & 91 & 78.3 & 92.0 & 65.6 & 11,5 \\
\hline 0.420 & 82 & 100 & 72.0 & 91.9 & 60.2 & 11,4 \\
\hline
\end{tabular}

Table 8. Computed data of refurbished turbo generator.

\begin{tabular}{|c|c|c|c|c|c|c|}
\hline $\begin{array}{c}\mathbf{Q} \\
{\left[\mathbf{m}^{\mathbf{3}} / \mathbf{s}\right]}\end{array}$ & $\begin{array}{c}\mathbf{a 0} \\
{[\mathbf{m m}]}\end{array}$ & $\begin{array}{c}\text { Guide vane } \\
\text { opening } \\
{[\mathbf{\%}]}\end{array}$ & $\begin{array}{c}\mathbf{\eta} \mathbf{H} \\
{[\mathbf{\%}]}\end{array}$ & $\begin{array}{c}\mathbf{\eta G}_{\mathbf{G}} \\
{[\mathbf{\%}]}\end{array}$ & $\begin{array}{c}\mathbf{\eta} \\
{[\mathbf{\%}]}\end{array}$ & $\begin{array}{c}\mathbf{P} \\
{[\mathbf{k W}]}\end{array}$ \\
\hline 0.139 & 29 & 35 & 65.0 & 87.0 & 51.5 & 3,2 \\
\hline 0.186 & 38 & 46 & 81.2 & 90.0 & 66.5 & 5,6 \\
\hline 0.243 & 48 & 59 & 88.0 & 91.0 & 72.9 & 8.0 \\
\hline 0.274 & 53 & 65 & 90.5 & 92.0 & 75.8 & 9,4 \\
\hline 0.322 & 62 & 76 & 91.0 & 92.0 & 76.2 & 11,1 \\
\hline 0.394 & 75 & 91 & 86.5 & 91.9 & 72.3 & 12,8 \\
\hline 0.420 & 82 & 100 & 83.0 & 91.8 & 69.3 & 13,1 \\
\hline
\end{tabular}

Tables above expressed in graphs show better the difference between old and new design.

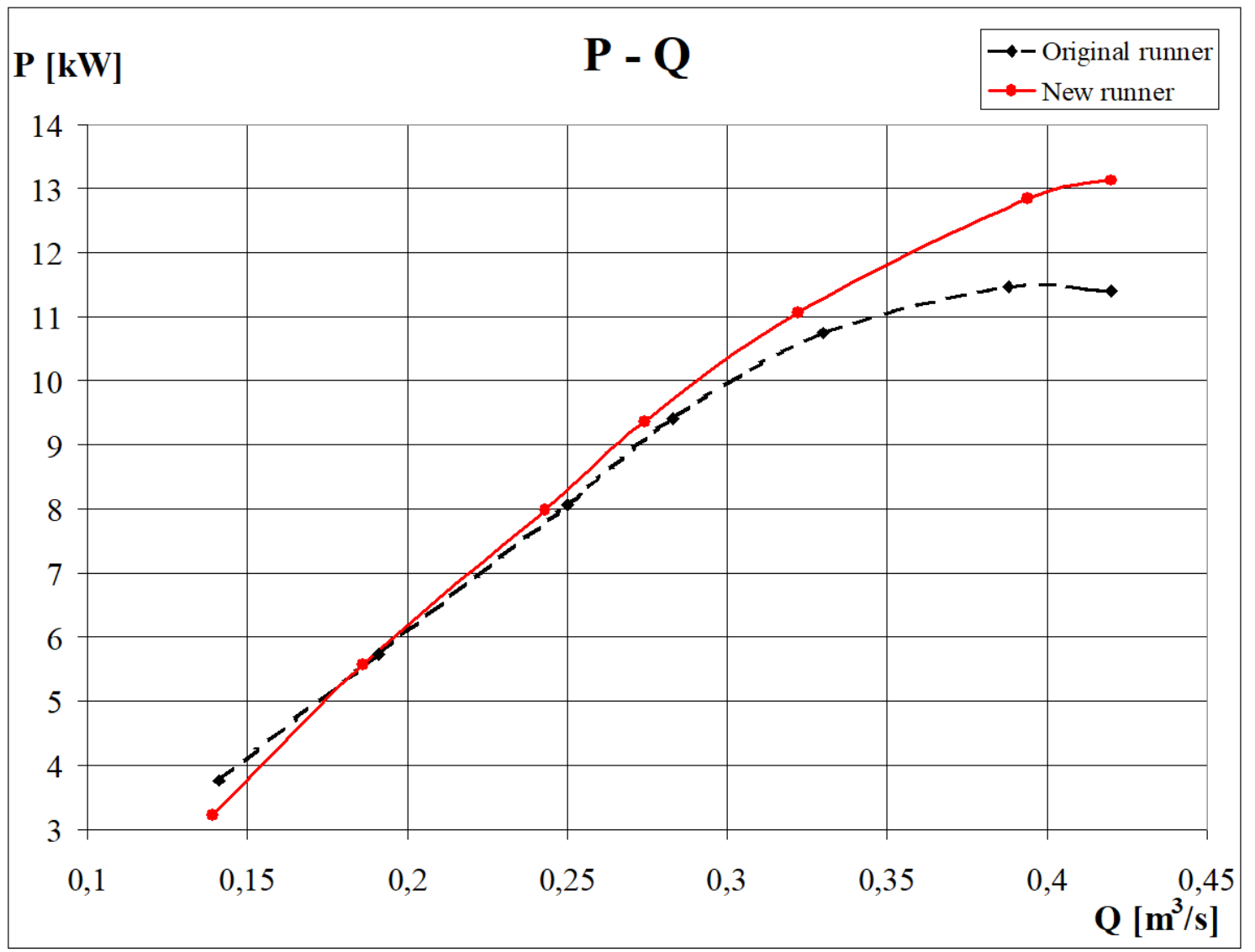

Graph 2. Computed data. 


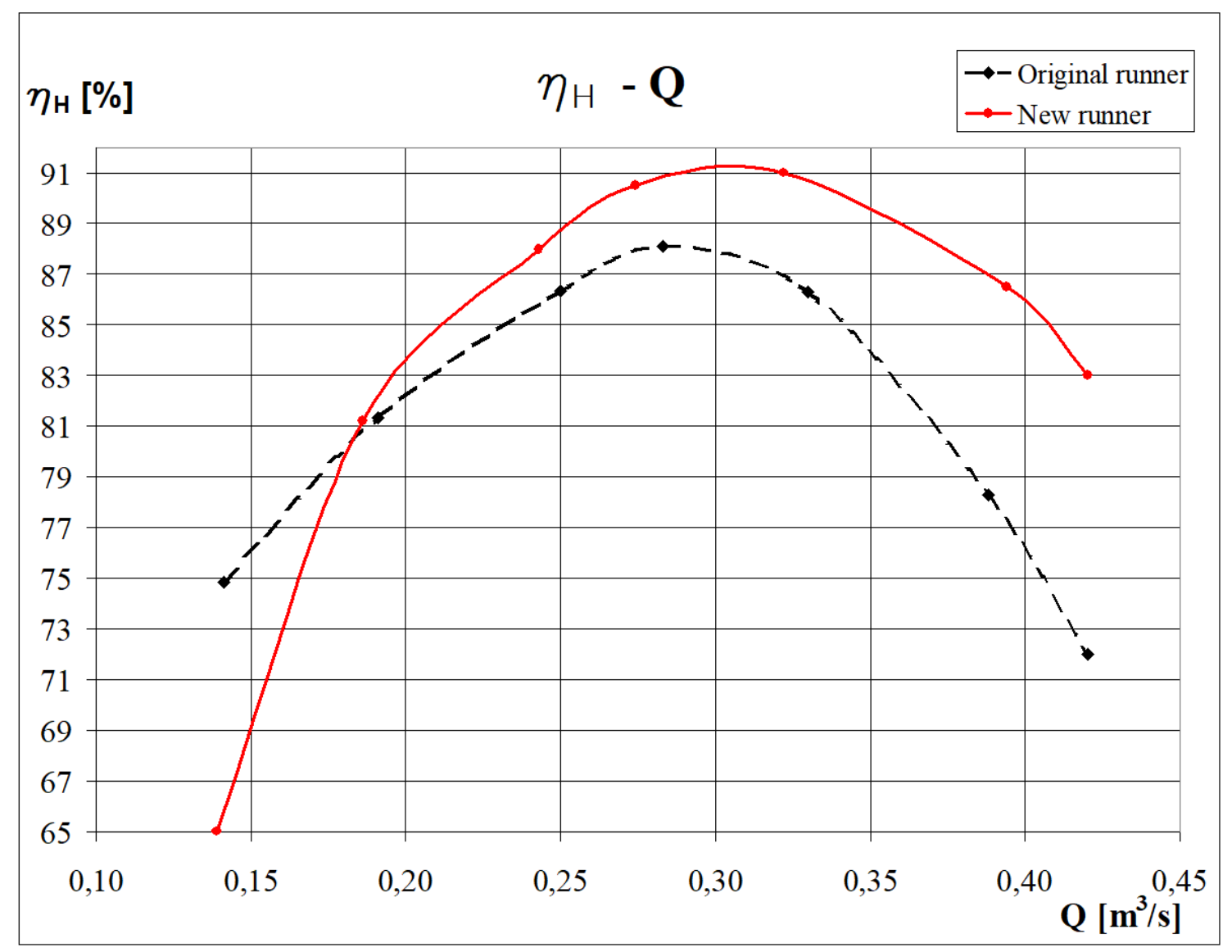

Graph 3. Computed data.

The only comparison of real and computed data can be done for dependency between guide vane opening and power output at given head. Reason is that no guarantee measurement takes place for such small turbines. See following graph. $100 \%$ opening means $\mathrm{a}_{0}=82 \mathrm{~mm}$ as given in table 5 .

To find out the reason for differences in efficiency of designs it is helpful to analyse streamlines going out of the runner into the draft tube. Ideal result is if they are not curly or even swirl. This should of course happen for operation point of the highest efficiency. Following comparison shows not only better shape of flow lines in the draft tube but also more uniform velocity which is desirable.

The other reason is the runner blade itself. See chapter 5.2. Concerning this it is worth noticing the importance of having more blades with sophisticated wing shape. Table 10 shows the difference between streamlines both in contour and velocity near blade. Again for optimum operation point. For this reason an offset surface by $0.1 \mathrm{~mm}$ from hub, shroud and blade has been constructed. Significantly worse streamlines and bigger range of velocity on the old runner give rise to also worse flow into the draft tube. 


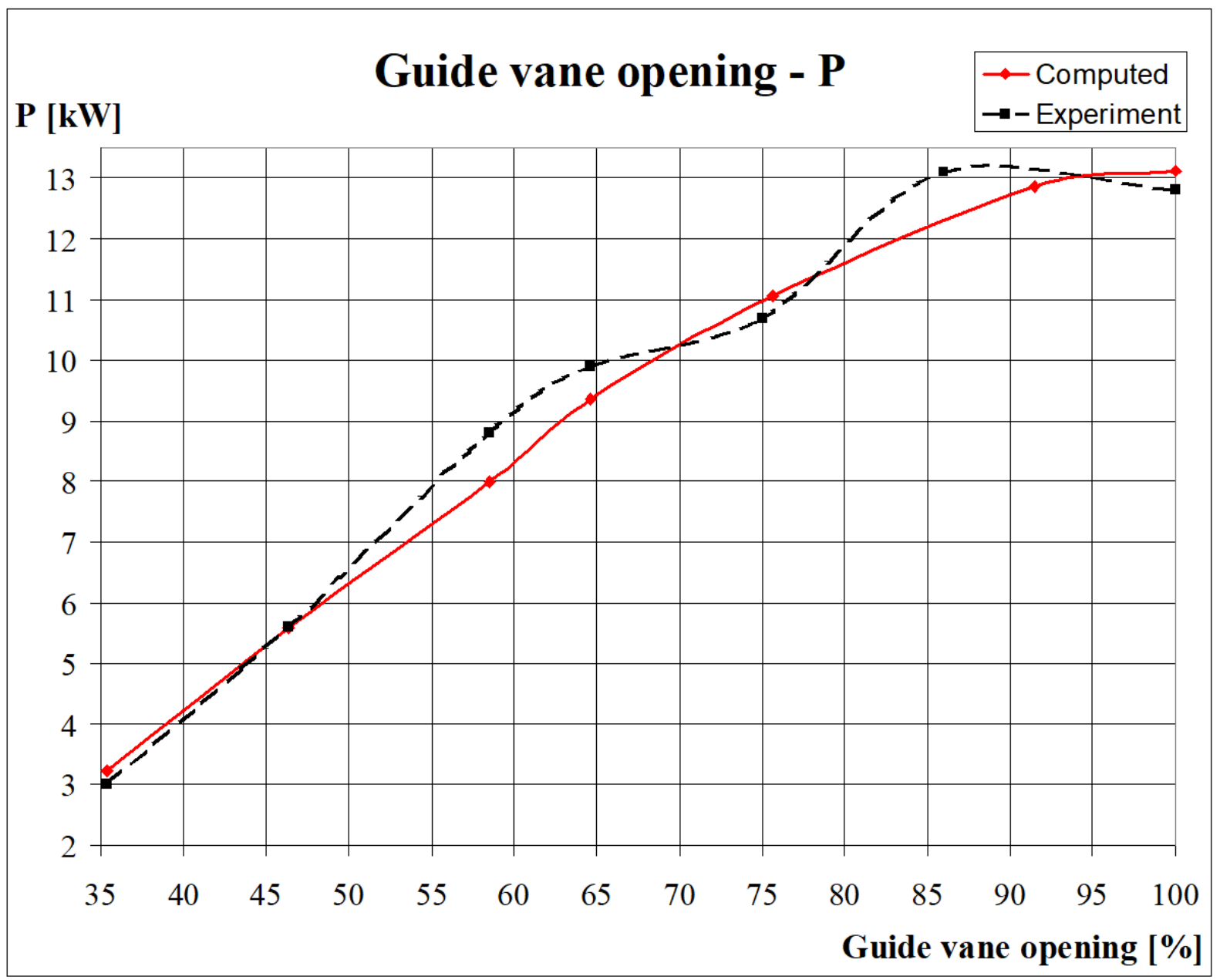

Graph 4. Experimental vs. computed data.

\section{Conclusions}

No guarantee measurement was done after the refurbishment. It is not performed in small power plants since it is expensive. Following figure 10 shows that the required electric power output value has been reached.

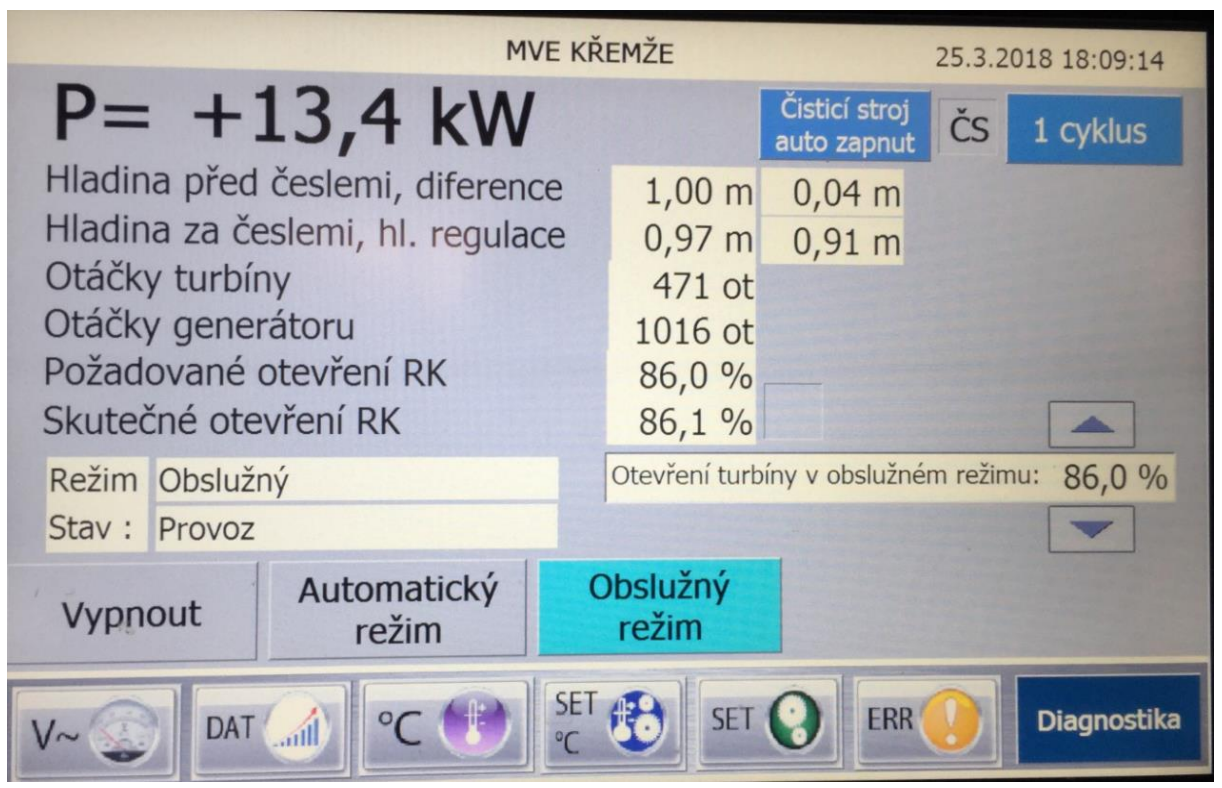

Fig. 10 Screen with the top power output. 
More sophisticated shape of runner blades resulted in better transformation of pressure into the power output together with less loss. This altogether enables to get quality power output of the turbo generator. That is to say that it is partially also due to better efficiency of new generator but author has no data about efficiency of the old one.

Table 9. Stream lines in midplane for top efficiency.

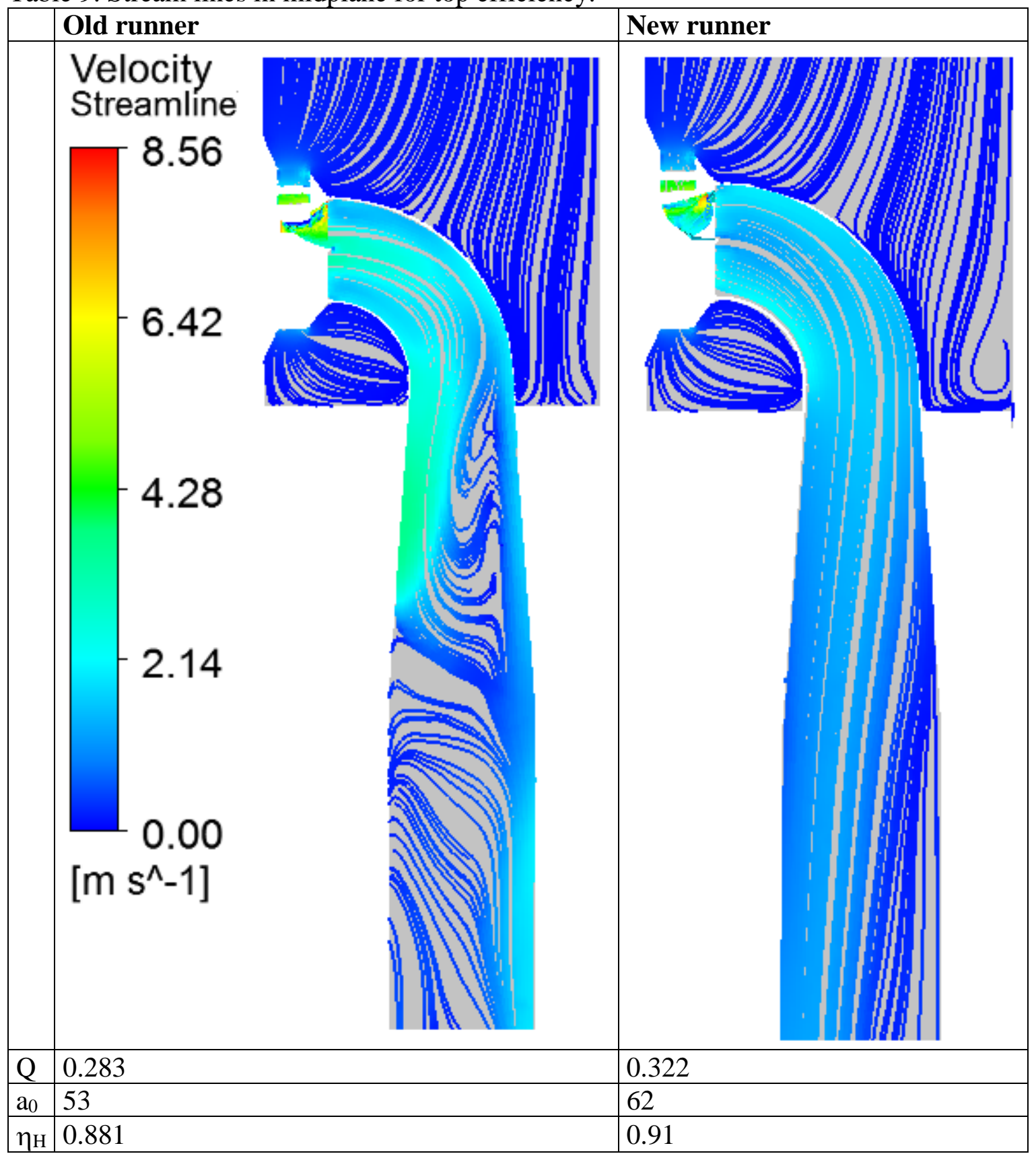

\subsection{Method error estimation}

Precise values of flow rate and net head were unknown. Error estimation comes from graph 4 and is taken for power output. Total power output $\mathrm{P}_{\exp }$ read in the screen is taken as a gauge.

$\mathrm{P}_{\text {comp }}$ and $\mathrm{P}_{\exp }$ stand for computed and experimental power output respectively.

$$
\begin{aligned}
& \Delta \mathrm{P}=\mathrm{P}_{\text {comp }}-\mathrm{P}_{\exp }[\mathrm{kW}] \\
& \text { Error }=\frac{\Delta \mathrm{P}}{\mathrm{P}_{\text {comp }}} 100[\%]
\end{aligned}
$$


Table 10. Streamlines on an offset surface. Pressure and suction side respectively.

\begin{tabular}{|l|l|l|l|}
\hline & Old runner & New runner \\
\hline & Velocity & Velocity \\
\hline & & \\
\hline
\end{tabular}

Table 11.

\begin{tabular}{|r|c|r|r|r|r|r|}
\hline $\begin{array}{c}\text { Guide vane } \\
\text { opening } \\
{[\%]}\end{array}$ & $\begin{array}{c}\mathbf{P}_{\text {comp }} \\
{[\mathbf{k W}]}\end{array}$ & $\begin{array}{c}\mathbf{P}_{\mathbf{e x p}} \\
{[\mathbf{k W}]}\end{array}$ & $\begin{array}{c}\Delta \mathbf{P} \\
{[\mathbf{k W}]}\end{array}$ & $\begin{array}{c}\text { Error+ } \\
{[\%]}\end{array}$ & $\begin{array}{c}\text { Error- } \\
{[\%]}\end{array}$ & $\begin{array}{c}\text { Error zero } \\
{[\%]}\end{array}$ \\
\hline 35 & 3.2 & 2.8 & 0.4 & 13 & & \\
\hline 46 & 5.6 & 5.6 & 0.0 & & & \\
\hline 59 & 8.0 & 8.8 & -0.9 & & -10 & \\
\hline 65 & 9.4 & 9.9 & -0.5 & & -5 & \\
\hline 75 & 11.0 & 10.7 & 0.3 & 3 & & \\
\hline 91 & 12.8 & 13.1 & -0.3 & & -2 & \\
\hline 100 & 13.1 & 12.8 & 0.3 & 2 & & \\
\hline
\end{tabular}




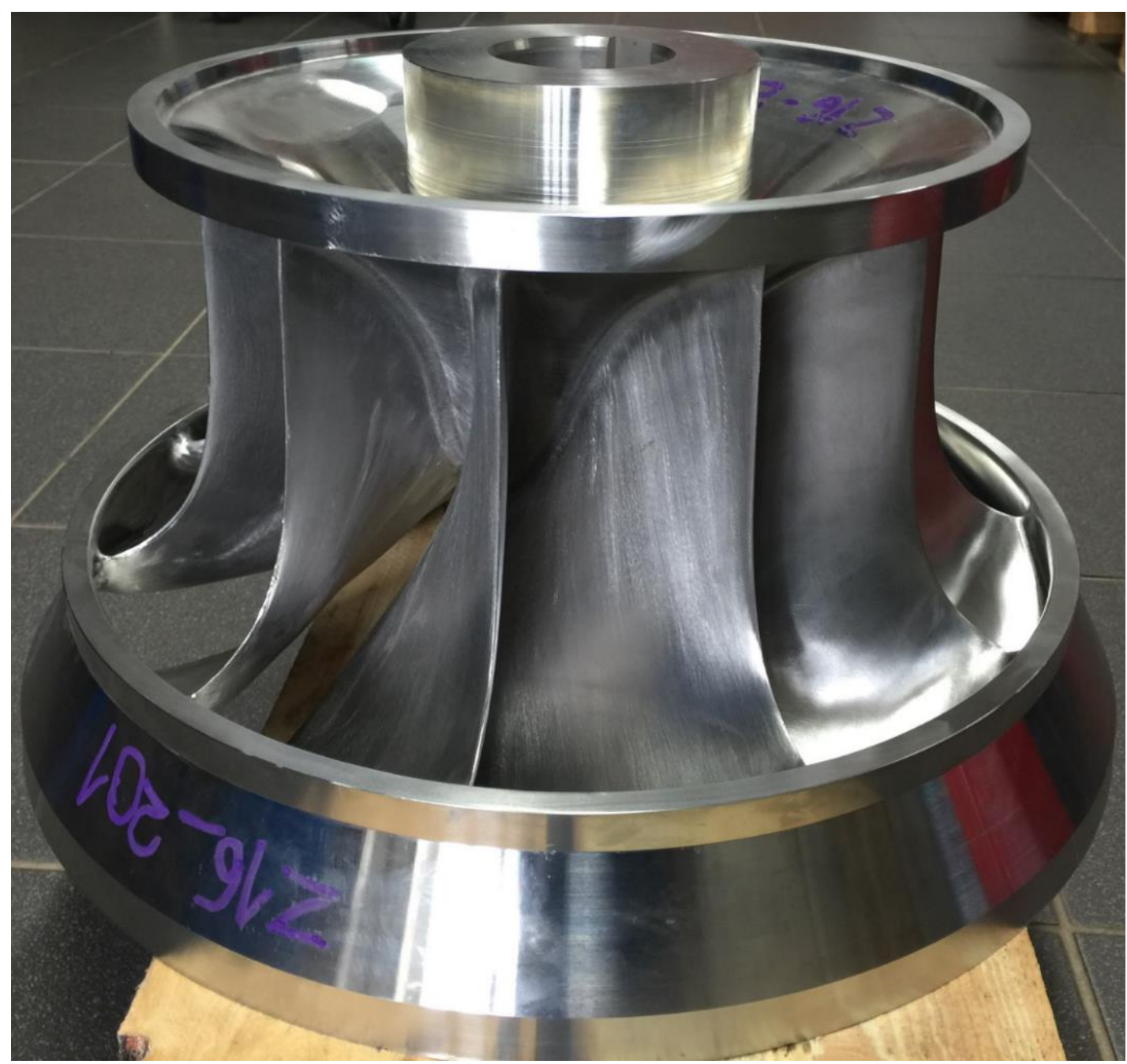

Fig. 11 New runner in the workshop after being machined.

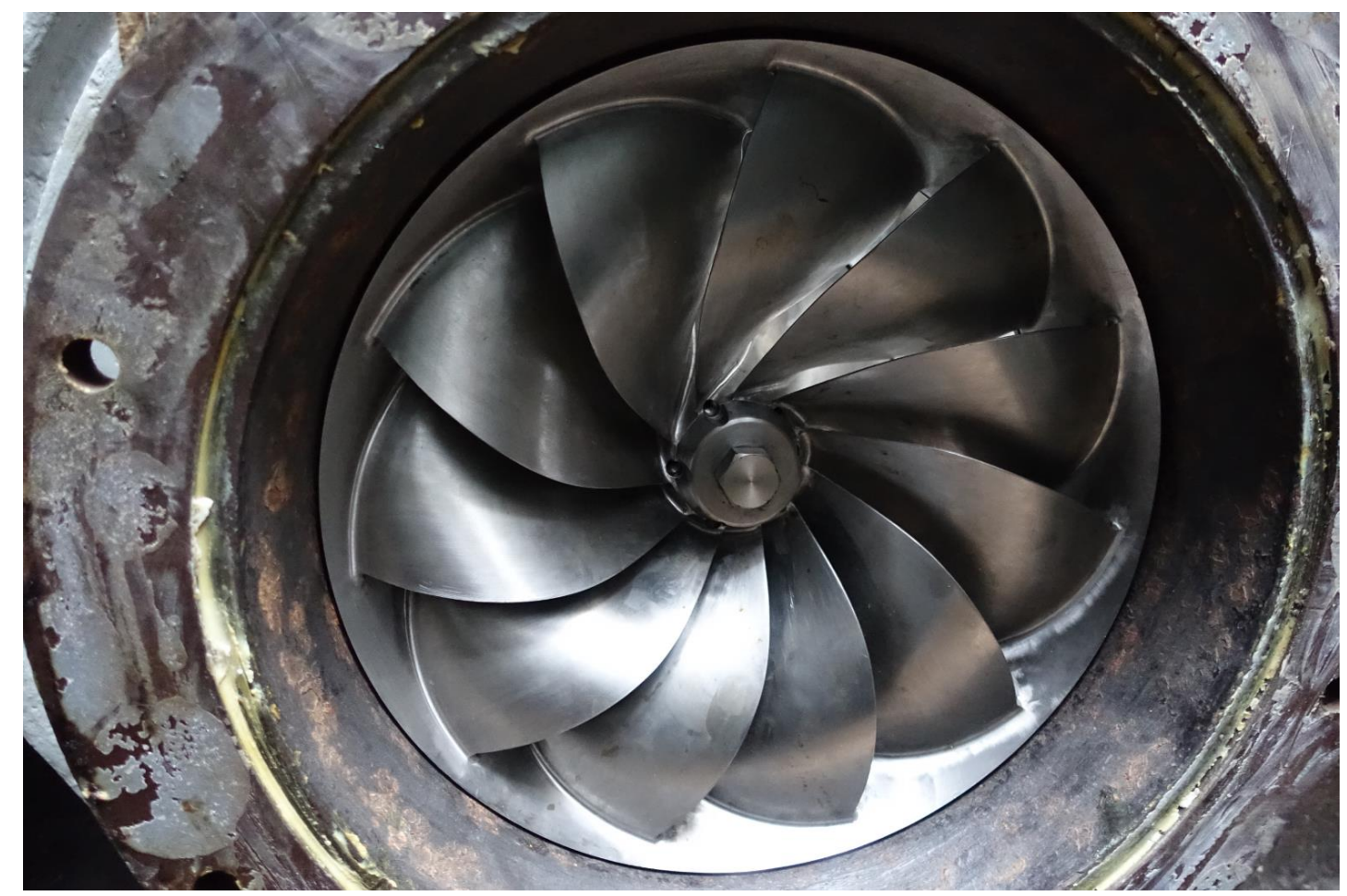

Fig. 12 New runner mounted into the turbine.

Volume 68, No. 3, (2018)

C 2018 SjF STU Bratislava 


$$
\begin{aligned}
& \text { Average Error }+=\frac{\sum \text { Error }+}{4}=4.4 \% \\
& \text { Average Error- }=\frac{\sum \text { Error }-}{4}=-4.4 \%
\end{aligned}
$$

Since usual error range in guarantee measurement is $\pm 2 \%$ [6] the result is acceptable.

\section{ACKNOWLEDGMENT}

I am grateful to Mr. Č́žzek the owner of the small power plant for providing me with original documentation, contemporary and original data and photographs.

\section{REFERENCES}

[1] https://en.wikipedia.org/wiki/Viktor_Kaplan

[2] Original technical documentation of Prokopa \& sons comp.

[3] Nechleba, M. Hydraulic Turbines, Their Design and Equipment, Constable \& Co Ltd. , 1957, $70-71$

[4] Energy Loss and Efficiency of Power Transmission Belts, Advanced Engineering Research, Carlisle Inc. , pp. 8, Fig. 4

[5] IEC 60193, Hydraulic Turbines, Storage Pumps and Pump-Turbines - Model Acceptance Tests , pp. 30

[6] IEC 60041, Field Acceptance Tests to Determine the Hydraulic Performance of Hydraulic Turbines, Storage Pumps and Pump-Turbines, pp. $39-41$, Appendix A, B, C, D

[7] Z. Csuka, R. Olšiak, Z. Fuszko. Research of Cavitation at High Shear Stress. Journal of Mechanical Engineering - Strojnicky časopis 2016 (66), No. 1, 7 - 16.

[8] V. Rek, I. Němec. Parallel Computation on Multicore Processors Using Explicit Form of the Finite Element Method and C++ Standard Libraries. Journal of Mechanical Engineering - Strojnícky časopis 2016 (66), No. 2, 67 - 78. 